\title{
Comparative Study on m-Learning Usage among LIS Students from Hong Kong, Japan and Taiwan
}

\begin{abstract}
Mobile learning (m-learning) is gaining its importance in recent years. For libraries, it is inevitable to adapt to this trend and provide various information services and support for mlearning. This paper studies the m-learning usage of Library and Information Science (LIS) students, who will be the new blood for the library in future. In this paper, we invited 267 subjects from Hong Kong, Japan, and Taiwan to participate in our online survey. We found that LIS students from these regions do adopt communication tools and social media for mlearning. However, they are less frequent to use their smartphones for academic reading. Plus, they rely more on search engines for fulfilling their information needs instead of library resources. We also found that the lacking of the mobile version website constitutes a significant barrier in m-learning, but the lacking of mobile apps is relatively acceptable by the respondents. The result of this study shows that there are no big differences in m-learning usage among the three regions, except that LIS students from Hong Kong are accessing the learning management platforms via their smartphones more frequently compared to students from Japan and Taiwan.
\end{abstract}

\section{Keywords}

Mobile learning (m-learning), Learning management platforms, Culture, Comparison, Smartphone, Library and information science (LIS) 


\section{INTRODUCTION}

A recent report released by the International Telecommunication Union (2014) showed estimated that the penetration rate of mobile broadband subscription will-reached $84 \%$ in the developed countries by the end of 2014. There are a lot of-Many scholars (Quinn, 2012; Rius, Masip, \& Clarisó, 2014; Sharples, Taylor, \& Vavoula, 2010; Traxler, 2009) єensidering considers that we are currently living in a mobile era in which most people can access to mobile networks and leave their digital footprint in the connected world at ease-(Quinn, 2012; Rius, Masip, \& Clarisó, 2014; Sharples, Taylor, \& Vavoula, 2010; Traxler, 2009). Eric Emerson Schmidt, the CEO of Google, even describes that people are treating their mobile devices as an extension of their person-own being (Claburn, 2007). This view was echoed by many scholars such as Sell, Walden, and Carlsson (2011) and Enders (2013), who opined that mobile devices are close to users not only physically, but also mentally by influencing how they interact with the world.

Mobile learning (m-learning) can be interpreted as learning via mobile devices. Indeed, there is already a long history of human applying technologies to learning activities (Fok, 2012), from adopting paper in ancient times, to the introduction of computer-assisted tools for e-learning. Recent development of mobile and wireless technologies opened up new possibilities in knowledge acquisition and learning experience (Yang, Hwang, Hung, \& Tseng, 2013). The pocket-sized mobile devices offer computer-like capabilities and Internet 
connectivity without restriction of time and venue (Henderson \& Chapman, 2012; Little, 2011). These unique features are drawing worldwide attention to the potential of m-learning in transforming the education landscape, as learners are now feasible to access, share and create knowledge anytime and anywhere (Binsaleh \& Binsaleh, 2013; Fok, 2012; Hyman, Moser, \& Segala, 2014; Koole, McQuilkin, \& Ally, 2010). This scenario motivates learners to actively participate in their learning, impelling a change from the traditional knowledge transmission approach to a learner-centered knowledge construction paradigm (Li, Lou, Tseng, \& Huang, 2013; Shih, Hwang, Chu, \& Chuang, 2011). In addition, m-learning provides learners with greater flexibility by accessing just-enough, just-in-time and just-for-me contents (Peters, 2007; Rosenberg, 2001), which enhances learning effectiveness and efficiency.

Given the new forms of learning mentioned above, it is impossible for libraries to ignore the potential impacts arising from m-learning, especially when mobile devices have already become major information accessing tools by their patrons (Lippincott, 2010). Libraries have strived to expand its information services to their patrons' mobile devices on a 24/7 basis already (Dresselhaus \& Shrode, 2012; Krishnan, 2011). For instance, many libraries have created their mobile version websites for enhancing experiences in accessing their services via mobile devices (Chandhok \& Babbar, 2011; Li, 2013; Seeholzer \& Salem, 
2011). Some libraries even developed their own mobile apps for patrons (Cummings, Merrill, \& Borrelli, 2010; Hahn \& Morales, 2011) to face this new change in the library environment.

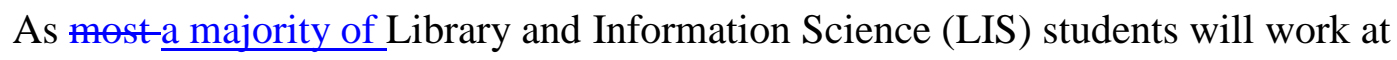
library after graduation, they will be among the core members to assist the-libraryies in adapting to m-learning. So, this research aims at studying the actual usage of m-learning by LIS students. Students from Hong Kong, Japan and Taiwan are selected for comparisons, as these regions are at a similar level of mobile technology adoption, yet with differences in culture. It is expected that this research could provide useful insight in m-learning usage by LIS students, in order to enable educators and researchers to assess the potential of m-learning and to incorporate emerging learner practices into the design of LIS education. Librarians could also gain insight in how libraries can meet or even exceed students' expectations in mlearning support from this research.

This paper is developed as follows. In the next section, we review the literature on the various aspects of mobile learning, and its impact on LIS. Then, we discuss our research objectives and questions, and-then our methodology, and-data collection, and the-data analysis. After the discussion of our findings and the limitation of this study, we conclude our paper with future research directions.

\section{LITERATURE REVIEW}

LITERATURE REVIEWON-M-LEARNING OVERVIEW 
M-learning is generally considered as an evolution of e-learning (Kitchenham, 2011;

Lu, Chang, Kinshuk, Huang, \& Chen, 2014; Morales, 2013; Stevens \& Kitchenham, 2011).

Currently, no single definition of m-learning is reached as mobile technology is still in a rapid changing field (Hockly, 2013; Kukulska-Hulme, 2009; Popescu, 2011). Some scholars opine that m-learning simply means learning via mobile devices (Chang, Littman-Quinn, \& Kovarik, 2013; Hyman et al., 2014; Stevens \& Kitchenham, 2011). Others focus on the mobility of the learner and learning activities (Bajpai, 2011; Binsaleh \& Binsaleh, 2013). Thus, many scholars prefer to use the definition provided by the MOBlearn project (O'Malley, Vavoula, Glew, Taylor, Sharples, \& Lefrer, 2003), which defines m-learning by incorporating the two major ideas mentioned above, i.e., m-learning is "any sort of learning that happens when the learner is not at a fixed, predetermined location, or learning that happens when the learner takes advantage of the learning opportunities offered by mobile technologies”. Plus, many scholars emphasized that m-learning should be able to let learners conduct seamless and ubiquitous learning unconstrained by time and place (Calbraith \& Dennick, 2011; Premkumar, 2011; Sharples, 2006).

In order to be engaged in m-learning, users need to have a mobile device to log into the m-learning system. However, the definition of mobile device evolves over time (Kukulska-Hulme et al., 2011). It can be ranging from laptops, PDAs, game consoles, MP3 players, e-book readers, netbooks, and then smartphones and tablets in recent years (Beseda, 
Machat, \& Palecek, 2012; Lippincott, 2010). Although laptops are still the most common mobile devices for study, more and more users are switching to use smartphones and tablets for academic purposes (Cummings et al., 2010). The device ownership comparisons conducted by Dahlstrom, Dziuban, and Walker (2013) as shown in Figure 1 confirmed the mentioned trends.

$<$ Insert Figure 1 here. $>$

Owing to comparatively larger screens and longer battery life, some scholars (Chen \& Denoyelles, 2013; Quinn, 2012) believed that the-tablets were the-mobile devices more appropriate for m-learning. However, other scholars suggested that mobile devices should be easily carried in the pocket (Premkumar, 2011; Wagner, 2008), so that users could bring with them wherever they go (Lippincott, 2010). Castle (2014) even criticized that treating tablets as mobile devices $\underline{\text { is }}$ a mistake, as he opined that the-a tablet higher portability. However, smartphones as are more suitable for m-learning as users interacted on a much more personal level with it when compared to a tablet.

Despite the fact that mobile devices are very popular nowadays, the adoption of mlearning in education is still far from an ideal stage (Little, 2011; Liu, Han, \& Li, 2010; Rajasingham, 2011). There are eomments-views that mobile devices are originally intended for communication and entertainment purposes instead of for educational use (Kinuthia \& Marshall, 2013; Peters, 2007; Taraszow, Borghs, \& Laouris, 2013). However, other scholars 
emphasize that success of m-learning still-depends largely on human factors rather than just on technology (Ally \& Prieto-Blázquez, 2014; Caudill, 2013). Therefore, the availability of mobile technology does not necessarily guarantee it will be used for learning (Bomhold, 2013; Elmorshidy, 2012; Mtebe \& Raisamo, 2014). For example, although some studies like Bomhold (2013) found that students did use their mobile devices for academic activities, other researchers (Alfawareh \& Jusoh, 2014; Gupta \& Manjrekar, 2012) had an opposite finding, i.e., they found out that students seldom used their mobile devices for learning and studying. Kim, Ilon, and Altmann (2013) even reported that those heavy users of mobile device have been-are usually not the most intensive-engaged m-learning users. Based on the autonomy feature of m-learning which that allows learners to take charge of their own learning progress (Liu et al., 2010; Sarrab, Al-Shihi, \& Hussain Rehman, 2013), it is generally agreed that m-learning is more suitable for self-regulated learning (Liu et al., 2010; Park \& Jung, 2013). Chu, Hwang, and Tsai (2010) even asserted that m-learning result in terms of learning outcomes could be disappointing without appropriate learning strategies.

Concerning the benefit of m-learning, one of the most apparent advantages is allowing users to access required information anytime and anywhere (Ally \& Prieto-Blázquez, 2014; Martin \& Ertzberger, 2013; Morales, 2013; Wesam, Gail, Elizabeth, \& Colin, 2013). It does not only implyies breaking of place and time barriers of learning (Enders, 2013), and enables while facilitating productive use of downtime (Mao, 2014; Morales, 2013; Negas \& Ramos, 
2011; Quinn, 2012) to become “stolen moment of learning” (Rajasingham, 2011, p. 3), but also allows timely access to required information at the point of actual need (Calbraith \& Dennick, 2011), which is also known as just-in-time learning (Liu, Geurtz, Karam, Navarrete, \& Scordino, 2013; Popescu, 2011; Sarrab et al., 2013). Plus, m-Learning allows learners to study according to their own preferences and needs (Koole et al., 2010; Rius et al., 2014; Sarrab et al., 2013), as well as to define their own speed of learning (Grunewald, Yang, \& Meinel, 2013; Taraszow et al., 2013). Personalized learning can, therefore, be realized with such tailor-made features (Gikas \& Grant, 2013; Popescu, 2011; Sarrab et al., 2013).

Other studies found that m-learning encourages learners to raise their difficulties and to express their opinions when compared to traditional learning (Kim, Lee, \& Kim, 2014; Ting, 2012). Features of mobility and instant connectivity also facilitate seamless interactions among learners (Kim et al., 2014; Ryu \& Parsons, 2012). Learners can engage in knowledge sharing and peer-based collaborative activities intensively (Hodgkinson-Williams \& Ng’ambi, 2009; Rambe \& Bere, 2013), forming “mobile learning knowledge networks” (Huang, Yang, Yueh-Min, \& Hsiao, 2010) or a-"mobile communities of practice” (Liu et al., 2013), which ultimately helps learners to achieve better learning outcomes. Other benefits include providing learners with up-to-date learning materials (Kim et al., 2014), extending learning beyond traditional classrooms (Rogers, 2011), serving as an external memory devices 
(Caverly, 2012) and saving of space and less in weight when compared to books and printed materials (Lea \& Callaghan, 2011), which can enhance the-overall learning experiences.

Nevertheless, m-lŁearning will never be a silver bullet for education. While it brings a lot of benefits, there are still a number of drawbacks. For instance, while the ability to have instant access of information is one of the generally accepted advantages of m-learning (Gikas \& Grant, 2013), this also encourages shallow learning (Handal, MacNish, \& Petocz, 2013) as learners believe that all information can be or even should be easily available whenever they need (Rajasingham, 2011). This illusion of easy access to all required knowledge may diminish the necessity of serious learning from some learners’ point of view (Chan, WalkerGleaves, \& Remedios, 2013). Another comment is related to use of downtime for m-learning. For example, Gikas and Grant (2013), Koole et al. (2010), and Traxler (2010) argued that this type of learning frequently suffered from interruptions, which resulted in fragmented and incomplete knowledge absorption processes, and eventually affected the quality of learning experience. Plus, physical constraints, such as the relatively small screen-size, constitute another barrier for the adoption of m-learning (Alzaza \& Yaakub, 2011; Kukulska-Hulme et al., 2011; Rogers, 2011). From a usability test, Nielsen (2011) concluded that a mobile screen was $48 \%$ on average harder to read compared to a desktop computer. Learners were, therefore, discouraged to read lengthy information from their mobile devices (Griggs, Bridges, \& Rempel, 2009; Rius et al., 2014). Difficulties in typing via small digital keyboards further 
discouraged learners to make detailed feedbacks and responses in their learning processes

(Kim et al., 2014; Rogers, 2011).

There are also concerns about the impact of m-learning on personal interactions. Mlearning might result in personal isolation, or at least learners missing the feeling of being physically together during the learning process (Sarrab, Elgamel, \& Aldabbas, 2012; Taraszow et al., 2013). As a result, some scholars advocated that m-learning could never hardly replace traditional face-to-face interventions (Binsaleh \& Binsaleh, 2013; KukulskaHulme, 2011). Other factors, like the instability of wireless networks (Handal et al., 2013), interoperability-incompatibility among mobile platforms (Kovachev, Cao, Klamma, \& Jarke, 2011; Rius et al., 2014; Sarrab et al., 2013), possible sources of distraction during lessons in traditional classes (Handal et al., 2013; Morales, 2013), and privacy concerns (Binsaleh \& Binsaleh, 2013; Cummings et al., 2010; Popescu \& Ghita, 2013) are also factors-hindering the development adoption of m-learning. LITERATURE REVIEW ON THE RELATIONSHIP BETWEEN LIS ANDOPPORTUNITIES AND THREATS OF M-LEARNING TO LIBRARIES

Development of mobile technology offers both opportunities and threats to libraries (Lippincott, 2010). It improves the accessibility of library services, but also-while imposes imposing competitions with libraryies in providing quick and convenient information (Griggs et al., 2009). Although over $70 \%$ of respondents declared that they would likely access 
library services via mobile devices (Dresselhaus \& Shrode, 2012), less than 15\% of college students selected library services as their top-three most frequently used services offered by their universities (Smith, Salaway, \& Caruso, 2009).

To face the-such impacts of m-learning in LIS, libraries should, therefore, identify the actual needs and usage of m-learning of their unique community (Chandhok \& Babbar, 2011; Dresselhaus \& Shrode, 2012; Krishnan, 2011). A mobile-friendly website with simple and minimalist design is essential for success (Nielsen \& Budiu, 2013). Besides, many libraries are starting to deliver their services via mobile platforms such as instant messaging/video reference services, assess to library catalogues and databases, QR (Quick Response) code based information services, borrowing records, facilities booking, library map and opening hours information (Dresselhaus \& Shrode, 2012; Krishnan, 2011; Little, 2011; Seeholzer \& Salem, 2011). However, Bomhold (2013) pointed out that providing easy-searching and accurate information were critical in attracting mobile users. Lippincott (2010) further suggested that librarians could add more values to users by advising efficient m-learning strategies and teaching information skills for users with their mobile devices. Plus, Aharony (2014) reminded that attitude of librarians in embracing the m-learning trends were also decisive for libraries to cope with the possible challenges in mobile era.

\section{RESEARCH OBJECTIVES AND QUESTIONS}


The role of m-learning is gaining its importance due to continuous growth in mobile device usage (Chen \& Denoyelles, 2013; Koszalka \& Ntloedibe-Kuswani, 2010; Song, 2011). Research towards m-learning also becomes one of the fastest growing fields with multidisciplinary participations (Kitchenham, 2011; Pachler, Bachmair, \& Cook, 2010; Wang \& Wang, 2013). However, many studies are focused on just technical aspects like mobile technologies and application development (Iglesia \& Weyns, 2013; Pocatilu, 2013; Serafimov, 2013) or self-developed library apps (Hahn \& Morales, 2011). Others are focused on the perception of m-learning (Gikas \& Grant, 2013; Gupta \& Manjrekar, 2012; Handal et al., 2013), comparing m-learning outcomes with other learning channels (Furió, GonzálezGancedo, Juan, Seguí, \& Rando, 2013; Kim et al., 2014) or mobile services available in libraries for users (Li, 2013). Relatively less research is focused on investigating the actual usage behavior of m-learning, especially for the LIS students. In addition, due to the rapid development of mobile technologies, there is a need to gain an up-to-date understanding on m-learning usage, as the mobile computing environment has changed radically with the recent diffusion of smartphones and mobile networks. There is a closely related research reported by Aharony (2014), who investigated the possible factors influencing m-learning adoption among LIS students in Israel. However, there is a lack of similar kind of study conducted in the East Asia, especially with cross-regional comparisons. 
Therefore, this study aims at bridging the research gap by studying the actual mlearning usage by LIS students from Hong Kong, Japan and Taiwan. Given the rationale discussed above, the focus this study will be on smartphone only. In particular, we are interested in the following five research questions:

RQ1: How often do LIS students use their smartphones for everyday life activities?

RQ2: How often do LIS students use their smartphones for m-learning activities?

RQ3: Which library services would LIS students like to access with their smartphones?

RQ4: What are the major barriers for LIS students in conducting m-learning activities?

RQ5: Do LIS students from Hong Kong, Japan and Taiwan behave differently in the questions listed above?

\section{METHODOLOGY AND DATA COLLECTION}

In this study, we employed a quantitative questionnaire to collect the responses from LIS students from Hong Kong, Japan and Taiwan, and compared their attitudes and behaviors on m-learning. The questionnaire was first prepared in English for our subjects in Hong Kong (see Appendix), and then-the Chinese and Japanese version of the questionnaires for our subjects in Taiwan and Japan, respectively, after the translated questionnaires were reviewed by native researchers to ensure error-freethe accuracy in the translation processes. 
The questionnaire contains 17 questions, which are adopted from prior research

(Bomhold, 2013; Kukulska-Hulme et al., 2011; Wilson \& McCarthy, 2010), and requires about 5-10 minutes to complete. Our subjects were first asked into response-respond to questions for collecting their demographic information such as gender, age, level of study and type of phone they used. Then, they were asked to respond to questions related to their habit of smartphone usage in everyday life. Afterwards, they were asked to respond to, followed by questions related to issues about-their m-learning experiences, as well as their experience in using online library services through their smartphones.

The questionnaire was distributed via SurveyMonkey.com. A pilot test was conducted in May 2014 using 13 respondents, which we confirmed that no further amendment was needed. The subjects of this study were LIS students from the University of Hong Kong, $\underline{\text { University of Tsukuba, and National Taiwan Normal University, } ө n e ~ p u b l i c ~ u n i v e r s i t i e s ~ e a c h ~}$ which are located in from-Hong Kong, Japan, and Taiwan, respectivity. The universities were chosen for pragmatic reasons, because of the researchers' affiliation with the institutions, while these institutions are also renowned ones offering LIS programmes in their respective regions. - Responses were collected on a voluntary basis. Research objective was declared at the beginning of the questionnaire. Informed consent was implied by submission of responses by the participants. A total of 267 responses was collected from $1^{\text {st }}$ June to $8^{\text {th }}$ September, $\underline{2014}$. 


\section{DATAANALYSIS}

\section{DEMOGRAPHIC INFORMATION}

Our data were collected using a Likert scale, and were analyzed using the statistical tools of Microsoft Excel and PHStat2 (Levine, Berenson, \& Stephan, 2011), i.e., add-ins designed for Microsoft Excel. The demographic background of our subjects is presented in Table 1. First, we noted that even though two-third of respondents are female, there is no significant difference in gender distribution among regions $(p>0.05)$. However, there is statistically significant between different- $\underline{\text { differences in the age profile of our datarespondents }}$ collected infrom Japan compared with the age profiles of our data collected-those from Hong Kong and Taiwan $(p<0.01)$. This may be caused by difference in level of study among the samples, as around two-third of respondents from Japan are undergraduate students $(p<0.01)$ instead of postgraduates.

< Insert Table 1 here. >

We also note that over $90 \%$ of the respondents own a smartphone. This result is similar to recent studies done by Chen and Denoyelles (2013) and Rung, Warnke, and Mattheos (2014), where the smartphone possession rate among of university students are 91\% and $88 \%$, respectively. Among those respondents with smartphones, over 93\% of them have subscribed mobile Internet service. The ratio of smartphone owners with Internet subscription is the lowest in Taiwan, despite the fact that respondents from Taiwan have a higher smartphone possession rate. 


\section{SMARTPHONE USAGE IN EVERYDAY LIFE}

The patterns of smartphone usage in everyday life of our subjects are summarized in Table 3. We found that the respondents overall frequently use smartphone for conducting communication, information searching, social activities, scheduling, note taking, and entertainment. Finding location, casual readings, and accessing reference information for travel, hobbies, sport and fitness purposes are reported with moderate frequency $\underline{\text { frequencies }}$ only. Surprisingly, our subjects access library services via their smartphones less than once per month on average, although all of them are LIS students.

$$
\text { < Insert Table } 3 \text { here. > }
$$

When comparing the frequency of smartphone usage pattern among regions, it seems that students from Hong Kong report a higher frequency in communication, entertainment and casual reading, while students from Japan are statistically lower in frequency ef $\underline{\text { in }}$ searching travel, hobbies, sport and fitness information, as well as the use of mobile banking and finance (as shown in Table 3). To present a more logical sense out of the data, we discover the need for the restriction of the following two factors (after a try-and-error process). The first one is ownership of smartphone with Internet subscription. It is reasonable to exclude those students without smartphones or mobile Internet access before conducting comparisons.

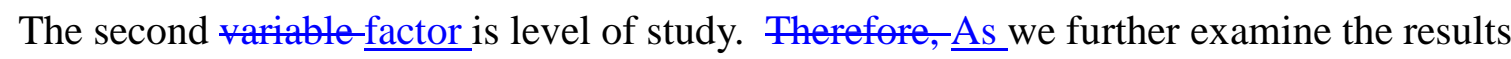


using just graduate students who have smartphone with Internet subscription,as-_shown in Table 4). In this subset, we noted that the behavioral differences among regions are no longer statistically significant except for the casual reading. Average frequency of smartphone usage is-generally increaseds too, except for library services which is-further deteriorates $\mathrm{d}$ indeed.

$$
\text { < Insert Table } 4 \text { here. > }
$$

When investigating the circumstances that respondents tend to use their smartphones to access the Internet, the top three responses are used for time-killing (82\%), when their computers is ise not available (80\%), and when quick answers isare needed (68\%), as shown in Table 5. However, results in Table 6 advises that the respondents often access the Internet via smartphones even though the-computers is-are easily available, especially for students from Hong Kong.

$$
\begin{aligned}
& <\text { Insert Table } 5 \text { here. > } \\
& <\text { Insert Table } 6 \text { here. }>
\end{aligned}
$$

\section{SMARTPHONE USAGE IN M-LEARNING}

Table 7 shows our respondents' m-learning frequency in browsing, reading, viewing and listening activities. Applying the same rationale mentioned above, we present both the overall results and the restricted results (i.e., only graduate students who have smartphones with Internet subscription). It is encouraging that LIS students engage in m-learning activities via browsing of social media and various types of websites on nearly a weekly basis on 
average. They also view video clips via smartphones for learning purposes on a monthly

basis on average. However, they rarely read e-books and journals via a smartphone. It is also found that LIS students from Hong Kong access learning management platforms (such as Moodle) more frequently when compared to Japan and Taiwan.

$<$ Insert Table 7 here. >

Similar to the above, we do not observe any significant difference from the restricted data when we look into the information searching and accessing frequency behavior of our subjects (see Table 8) and as well as the use of productivity tools (see Table 9) among the three regions. Apparently, respondents rely more frequently on search engines for fulfilling their information needs instead of library resources, which is consistent with the trends in academic library as mentioned by Little (2012).

$$
\begin{aligned}
& \text { < Insert Table } 8 \text { here. > } \\
& \text { < Insert Table } 9 \text { here. > }
\end{aligned}
$$

In our sample, texting by smartphones is the most frequent usage for learning purposes. Voice discussion comes next. Social media is another common channel for respondents to

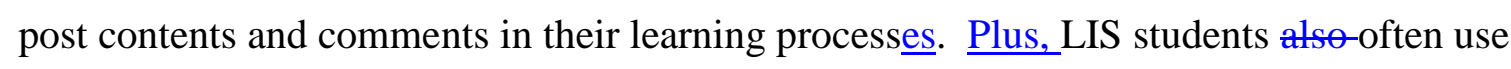
their smartphones to share files, photos and videos for academic purposes. However, they seldom use social bookmarking and QR codes for learning. This concurs with the may be explained by findings from Cassidy et al. (2014) that 75.3\% of their students did not use QR 
code readers. More respondents from Hong Kong participate in class forums via learning platforms. This, which is consistent with the mentioned result relating to learning management platforms. Results in Table 10 indicates that respondents from Japan are comparatively less frequent to conduct voice discussion with a smartphone for learning purposes. It might be due to the cultural difference as most Japanese would feel ashamed to talk over the-mobile phones in the public area (Humphreys, 2005).

$<$ Insert Table 10 here. $>$

We also explored the use of mobile devices to create records for academic purposes by LIS students. Our results are, as summarized in Table 11. Our subjects from Taiwan are comparatively more active in creating videos for learning purposes, but their frequency in doing this is still less than monthly on average. Most LIS students in-from Japan never use their smartphones to record seminars or talks for academic purposes.

< Insert Table 11 here. >

Among the online library services available (see Table 12), we noted that checking the library catalog is the most eommonly used-popular service with over half of the respondants LIS students-already accessing this via their smartphones. Checking library hours and map ranked second. Contacting a librarian via smartphone is the least used service. Over $40 \%$ of LIS students are not interested in it even if this service is available. This finding is similar to responses collected in another research done-by Dresselhaus and Shrode (2012), where only 
$9 \%$ and $15 \%$ of the respondents used smartphones to contact the librarians via texting and instant messaging, respectively (although participants in-their research-respondants are not LIS students). Facility booking via smartphones is the most eagerly expected service if available, especially for the respondents from Taiwan. Over $45 \%$ of the respondents would also like to access electronic resources and their library account by smartphones if these services were available. It is notable that nearly $60 \%$ of LIS students from Hong Kong have already accessed their library accounts by smartphones, which is significantly higher than students form Japan and Taiwan.

$<$ Insert Table 12 here. $>$

Concerning the barriers for participating in m-Learning-learning by our subjects, the top two are lacking of a mobile version website and limited screen size of a-smartphones, as suggested in Table 13. It is followed by formatting problem of contents and response time. Difficulty in typing is deemed as lower than medium barrier. Surprisingly, lack of mobile apps ranks the second least important barrier only. Another interesting point is network factor, which is not emphasized by most respondents from Hong Kong and Japan, but ranked as the second highest barrier by LIS students from Taiwan.

< Insert Table 13 here. >

\section{DISCUSSION}

Most of LIS students are already equipped with necessary devices for m-learning. They also get used to accessing the Internet with smartphones, especially for day-to-day 
communication and social activities. Learning activities involving communications and social media are also widely adopted. However, the frequency of reading e-books and journals by smartphones for academic purposes are much lower when compared with casual readings. As the definition of casual reading provided in the questionnaire included comics, magazines and newspapers, it is argued that students are less inclined to read lengthy articles with their smartphones. LIS educators may need to pay attention to this fact when designing m-learning materials.

It is noted that no matter of everyday life and-or m-learning purposes, LIS students prefer using search engines to library resources for fulfilling their information needs. It seems that even though libraries are proud for their provision availability-of high quality information sources, respondents are satisfied with user-friendly searching experience with 'good-enough' information retrieved from search engines.

When it comes to assessing library services via smartphones, it is interesting that there is a large portion of students asserting that they would like to use those services if they were available. As there are also-some respondents also indicateing that they are already using those services, it is most likely that some students had not been informed that of the availability of these-those services-were actually available for their access. Cassidy et al. (2014) further supported this claim and wrote that "although students positively responded to receiving library services via various technologies, many remain unaware of some services 
their library already provides”. Therefore, more publicity of the availability of these services is required.

It is also interesting that most LIS students do not have concerns on the availability of mobile apps for m-learning. However, they considered that it would be a relatively high barrier if there was no mobile version of the library website. This may be a good news for librarians in era of shrinking budgets, as resources can be focused on developing only an effective mobile website, instead of developing both apps and mobile sites. However, it is sure that the use of online library services will be discouraged if they are incompatible with their mobile devices, as suggested by Cassidy et al. (2014).

Last but not least, our results of this survey-suggest that there are actually no big differences in m-learning usage among LIS students from Hong Kong, Japan and Taiwan. As suggested by the Hofstede Cultural Dimensions (Hofstede, 2001), these three countries are having quite different values in the five aspects of their cultural dimensions (see Table 14), except in power distance, which measures "the extent to which the less powerful members of institutions and organizations within a country expect and accept that power is distributed unequally”. Prior research (Calvert, 2001) also reported that-power distance is the most significant cultural dimension which that has influence in the expectation in library services between the cultures of China and New Zealand. Therefore, we would suggest that the-similar results found among the three countries covered in this study is consistent with the findings 
about above and can provide us with a better understanding of the expectation of LIS students on m-learning.

There are several limitations in this survey. For instance, we only collect samples from one university each of the three countries studied (though they are well-known universities for LIS programmes), which may not be representative enough for the entire population there. Therefore, we suggest that further investigation using samples collected from multiple universities in these countries is preferred. Second, as we relied on an online questionnaire as a sole channel for collecting responses, this study may suffer from inherent bias, i.e., candidates who are less familiar with the Internet may be discouraged from participating from this study. Third, due to the difference of the enrollment of the LIS programs in these three universities, the number of respondents from Japan was much more than the numbers from Hong Kong and Taiwan, and the respondents are coming from different types of programs (i.e., the participants from Hong Kong and Taiwan are mainly graduate students, and those from Japan are mainly undergraduate students). Therefore, cluster sampling is proposed for future studies in order to avoid a similar problem. In addition, while quantitative data are convenient for measuring differences among regions with statistical testing techniques, it is weak at exploring the underlying reasons for the phenomenon found. This research could be enriched by incorporating qualitative data collection methods such as in-depth focus group interviews, i.e., using the mixed methods 
methodology (Bryman, 2007). Such qualitative data collected could also be used for triangulation in order to ensure the reliability of the research results.

\section{CONCLUSION}

It is predicted that mobile devices will become-is becoming a widely used learning device in the near futtre-(Norris, Hossain, \& Soloway, 2011). Dougherty (2010) also predicted that mobile information patrons will surely be increased given the prevalence of wireless data communication technology. For LIS students, who will pursue their career as librarians after graduation, this is necessary for them to get familiar with m-learning techniques, to identify usage habits of learners, and to recognize recent trends and development of m-learning. Incumbent librarians are even more in need to study and implement strategic responses for the coming wave of m-learning. This study provides important reference of m-learning usage of LIS students from Hong Kong, Japan and Taiwan. Their characteristics of m-learning usages are-have also been highlighted. It is expected that result in this study could serve as a good reference for future researches.

\section{REFERENCES}

Aharony, N. (2014). Library and information science students' perceptions of m-learning. Journal of Librarianship and Information Science, 46(1), 48-61.

Alfawareh, H. M., \& Jusoh, S. (2014). Smartphones usage among university students: Najran University case. International Journal of Academic Research, 6(2), 321-326. 
Ally, M., \& Prieto-Blázquez, J. (2014). What is the future of mobile learning in education? RUSC, 11(1), 142-151.

Alzaza, N. S., \& Yaakub, A. R. (2011). Students' awareness and requirements of mobile learning services in the higher education environment. American Journal of Economics and Business Administration, 3(1), 95-100.

Bajpai, B. R. (2011). M-learning \& mobile knowledge management: Emerging new stages of e-learning \& knowledge management. International Journal of Innovation, Management and Technology, 2(1), 65.

Beseda, J., Machat, Z., \& Palecek, L. (2012). M-learning as a trend. PRADEC Conference Proceedings, 1(1), 32-38.

Binsaleh, S., \& Binsaleh, M. (2013). Mobile learning: What guidelines should we produce in the context of mobile learning implementation in the conflict area of the four southernmost provinces of Thailand. Asian Social Science, 9(13), 270-281.

Bomhold, C. R. (2013). Educational use of smart phone technology: A survey of mobile phone application use by undergraduate university students. Electronic Library and Information Systems, 47(4), 426-436.

Bryman, A. (2007). Barriers to integrating quantitative and qualitative research. Journal of Mixed Methods Research, 1(1), 8-22. 
Calbraith, D., \& Dennick, R. (2011). Producing generic principles and pedagogies for mobile learning: A rigorous five part model. In A. Kitchenham (Ed.), Models for Interdisciplinary Mobile Learning: Delivering Information to Students (pp. 26-48). Hershey, PA: Information Science Reference.

Calvert, P. J. (2001). International variations in measuring customer expectation. Library Trends, 49(2), 732-757.

Cassidy, E. D., Colmenares, A., Jones, G., Manolovitz, T., Shen, L., \& Vieira, S. (2014). Higher education and emerging technologies: Shifting trends in student usage. The Journal of Academic Librarianship, 40(2), 124-133.

Castle, R. (2014). Five mobile learning mistakes to avoid. Training \& Development, 41(2), 21.

Caudill, J. G. (2013). Mobile learning and traditional students: New standards for interaction and accessibility. In W. Kinuthia \& S. Marshall (Eds.), On the Move: Mobile Learning for Development (pp. 3-23). Charlotte, NC: Information Age Publishing, Inc.

Caverly, D. C. (2012). Techtalk: 13a-mobile learning and the knowledge age. Journal of Developmental Education, 36(1), 32-33.

Chan, N. N., Walker-Gleaves, A., \& Remedios, R. (2013). Ubiquitous learning: The lived experience of students learning with smartphones. In A. Foley (Ed.), Proceedings of the Sixh Conference of MIT's Learning International Networks Consortium (LINC 2013). 
Chandhok, S., \& Babbar, P. (2011). M-learning in distance education libraries. The Electronic Library, 29(5), 637-650.

Chang, A. Y., Littman-Quinn, R., \& Kovarik, C. L. (2013). Use of mobile learning to train healthcare workers in resource-limited settings. In W. Kinuthia \& S. Marshall (Eds.), On the Move: Mobile Learning for Development (pp. 197-208). Charlotte, NC: Information Age Publishing, Inc.

Chen, B., \& Denoyelles, A. (2013). Exploring students' mobile learning practices in higher education. EDUCAUSE Review Online. Retrieved November 2, 2014, from http://www.educause.edu/ero/article/exploring-students-mobile-learning-practiceshigher-education

Chu, H. C., Hwang, G. J., \& Tsai, C. C. (2010). A knowledge engineering approach to developing mindtools for context-aware ubiquitous learning. Computers \& Education, 54(1), 289-297.

Claburn, T. (2007). CEO Eric Schmidt presents Google's friendly face at Web 2.0 Expo. Retrieved November 1, 2014, from http://www.informationweek.com/ceo-ericschmidt-presents-googles-friendly-face-at-web-20-expo/d/d-id/1054142?

Cummings, J., Merrill, A., \& Borrelli, S. (2010). The use of handheld mobile devices: their impact and implications for library services. Library Hi Tech, 28(1), 22-40. 
Dahlstrom, E., Dziuban, C., \& Walker, J. (2013). ECAR study of undergraduate students and information technology. EDUCAUSE Center for Applied Research, Louisville, CO.

De la Iglesia, D. G., \& Weyns, D. (2013). Guaranteeing robustness in a mobile learning application using formally verified MAPE loops. In: Proceedings of 2013 ICSE Workshop on Software Engineering for Adaptive and Self-Managing Systems (SEAMS' 13) (pp. 83-92), San Francisco, CA.

De Vaus, D. A. (2002). Analyzing Social Science Data. London:UK SAGE.

Dougherty, W. C. (2010). Managing technology in libraries: A look to the past with hope for the future. The Journal of Academic Librarianship, 36(6), 543-545.

Dresselhaus, A., \& Shrode, F. (2012). Mobile technologies \& academics: Do students use mobile technologies in their academic lives and are librarians ready to meet this challenge? Information Technology and Libraries (Online), 31(2), 82-101.

Elmorshidy, A. P. (2012). Mobile learning - A new success model. Journal of Global Business Management, 8(2), 18-27.

Enders, B. J. (2013). Manager's Guide to Mobile Learning. New York:NY, McGraw-Hill.

Fok, W. (2012). The new era of e-learning: Mobile learning \& interactive class for the new curriculum. Hong Kong: University of Hong Kong. 
Furió, D., González-Gancedo, S., Juan, M. C., Seguí, I., \& Rando, N. (2013). Evaluation of learning outcomes using an educational iPhone game vs. traditional game. Computers \& Education, 64, 1-23.

Gikas, J., \& Grant, M. M. (2013). Mobile computing devices in higher education: Student perspectives on learning with cellphones, smartphones \& social media. Internet and Higher Education, 19, 18-26.

Griggs, K., Bridges, L. M., \& Rempel, H. G. (2009). Library/mobile: Tips on designing and developing mobile Web sites. The Code4Lib Journal, 8. Retrieved November 12, 2014, from http://journal.code4lib.org/articles/2055

Grunewald, F., Yang, H., \& Meinel, C. (2013). Evaluating the digital manuscript functionality - User testing for lecture video annotation features. In J.-F. Wang \& R. Lau (Eds.), Advances in Web-based Learning ICWL 2013: 12th International Conference, Kenting, Taiwan, October 6-9, 2013: Proceedings (pp. 214-223). Berlin, Germany: Springer.

Gupta, M., \& Manjrekar, P. (2012). Using mobile learning to enhance quality in higher education. SIES Journal of Management, 8(1), 23-30.

Hahn, J., \& Morales, A. (2011). Rapid prototyping a collections-based mobile wayfinding application. The Journal of Academic Librarianship, 37(5), 416-422. 
Handal, B., MacNish, J., \& Petocz, P. (2013). Adopting mobile learning in tertiary environments: Instructional, curricular and organizational matters. Education Sciences, 3(4), 359-374.

Henderson, R. G., \& Chapman, B. F. (2012). Business educators' perceptions concerning mobile learning (M-Learning). Delta Pi Epsilon Journal, 54(1), 16-26.

Hockly, N. (2013). Mobile learning. ELT Journal, 67(1), 80-84.

Hodgkinson-Williams, C., \& Ng’ambi, D. (2009). Case study 5: Mobile learning: Report of the opening scholarship project. Cape Town: Centre of Educational Technology. Retrieved November 9, 2014, from http://www.cet.uct.ac.za/files/file/OS\%20CaseStudy5\%20_\%20\%20Final\%20typeset. pdf

Hofstede, G. (2001). Cultural Consequences: Comparing Values, Behaviors, Instutitions and Organizations across Nations. Thousand Oaks, CA: Sge Publication.

Huang, J. J. S., Yang, S. J. H., Yueh-Min, H., \& Hsiao, I. Y. T. (2010). Social learning networks: Build mobile learning networks based on collaborative services. Journal of Educational Technology \& Society, 13(3), 78-92.

Humphreys, L. (2005). Cellphones in public: social interactions in a wireless era.New media \& society, 7(6), 810-833. 
Hyman, J. A., Moser, M. T., \& Segala, L. N. (2014). Electronic reading and digital library technologies: Understanding learner expectation and usage intent for mobile learning. Educational Technology Research and Development, 62, 35-52.

International Telecommunication Union. (2014). ICT Facts and Figures. Retrieved November 4, 2014, from http://www.itu.int/en/ITUD/Statistics/Documents/facts/ICTFactsFigures2014-e.pdf

Kim, H., Lee, M., \& Kim, M. (2014). Effects of mobile instant messaging on collaborative learning processes and outcomes: The case of South Korea. Journal of Educational Technology \& Society, 17(2), 31-42.

Kim, J., Ilon, L., \& Altmann, J. (2013). Adapting smartphones as learning technology in a Korean University. Journal of Integrated Design and Process Science, 17(1), 5-16.

Kinuthia, W., \& Marshall, S. (2013). Introduction. In W. Kinuthia \& S. Marshall (Eds.), On the Move: Mobile Learning for Development (pp. xi-xvi). Charlotte, NC: Information Age Publishing, Inc.

Kitchenham, A. (2011). Preface. In A. Kitchenham (Ed.), Models for Interdisciplinary Mobile Learning: Delivering Information to Students (pp. xix-xxv). Hershey, PA: Information Science Reference.

Koole, M., McQuilkin, J. L., \& Ally, M. (2010). Mobile learning in distance education: Utility or futility? Journal of Distance Education (Online), 24(2), 59-82. 
Koszalka, T. A., \& Ntloedibe-Kuswani, G. S. (2010). Literature on the safe and disruptive learning potential of mobile technologies. Distance Education, 31(2), 139-157.

Kovachev, D., Cao, Y., Klamma, R., \& Jarke, M. (2011). Learn-as-you-go: New ways of cloud-based micro-learning for the mobile Web. In H. Leung, E. Popescu, Y. Cao, R. W. H. Lau \& W. Nejdl (Eds.), Advances in Web-based Learning - ICWL 2011: 10th International Conference, Hong Kong, China, December 8-10, 2011: Proceedings (pp. 51-61), London, UK: Springer.

Krishnan, Y. (2011). Libraries and the mobile revolution. Computers in Libraries, 31(3), 69,40 .

Kukulska-Hulme, A. (2009). Will mobile learning change language learning? ReCALL: The Journal of EUROCALL, 21(2), 157-165.

Kukulska-Hulme, A. (2011). Smart learning with mobile devices? Retrieved November 12, 2014, from http://blogs.ubc.ca/newliteracies/files/2011/12/Kukulska-Hulme.pdf

Kukulska-Hulme, A., Pettit, J., Bradley, L., Carvalho, A. A., Herrington, A., Kennedy, D. M., \& Walker, A. (2011). Mature students using mobile devices in life and learning. International Journal of Mobile and Blended Learning, 3(1), 18-52.

Lea, S., \& Callaghan, L. (2011). Enhancing health and social care placement learning through mobile technology. Journal of Educational Technology \& Society, 14(1), 135-145. 
Levine, D. M., Berenson, M. L., \& Stephan, D. (2011). Statistics for Managers Using Microsoft Excel. Boston, MA: Pearson.

Li, A. (2013). Mobile library service in key Chinese academic libraries. The Journal of Academic Librarianship, 39(3), 223-226.

Li, K.-H., Lou, S.-J., Tseng, K.-H., \& Huang, H.-C. (2013). A preliminary study on the Facebook-based learning platform integrated with blended learning model and flip learning for online and classroom learning. In J.-F. Wang \& R. Lau (Eds.), Advances in Web-based Learning ICWL 2013: 12th International Conference, Kenting, Taiwan, October 6-9, 2013: Proceedings (pp. 172-183). Berlin, Germany: Springer.

Lippincott, J. K. (2010). A mobile future for academic libraries. Reference Services Review, 38(2), 205-213.

Little, G. (2011). Keeping moving: Smart phone and mobile technologies in the academic library. The Journal of Academic Librarianship, 37(3), 267-269.

Little, G. (2012). Where are you going, where have you been? The evolution of the academic library Web site. The Journal of Academic Librarianship, 38(2), 123-125.

Liu, M., Geurtz, R., Karam, A., Navarrete, C., \& Scordino, R. (2013). Research on mobile learning in adult education. In W. K. S. Marshall (Ed.), On the Move: Mobile Learning for Development (pp. 105-160). Charlotte, NC: Information Age Publishing, Inc. 
Liu, Y., Han, S., \& Li, H. (2010). Understanding the factors driving m-learning adoption: A literature review. Campus - Wide Information Systems, 27(4), 210-226.

Lu, C., Chang, M., Kinshuk, Huang, E., \& Chen, C.-W. (2014). Context-aware mobile role playing game for learning - A case of Canada and Taiwan. Journal of Educational Technology \& Society, 17(2), 101-114.

Mao, C. (2014). Research on undergraduate students' usage satisfaction of mobile learning. Creative Education, 5(8), 614-618.

Martin, F., \& Ertzberger, J. (2013). Here and now mobile learning: An experimental study on the use of mobile technology. Computers \& Education, 68, 76-85.

Morales, L. (2013). What is mLearning and how can it be used to support learning and teaching in Econometrics? Higher Learning Research Communications, 3(1), 18-37.

Mtebe, J. S., \& Raisamo, R. (2014). Investigating students' behavioural intention to adopt and use mobile learning in higher education in East Africa. International Journal of Education and Development using Information and Communication Technology, 10(3), 4-20.

Negas, M. C., \& Ramos, P. (2011). Critical factors in the use of mobile learning by "Digital Natives" on Portuguese teaching. In K. Grant (Ed.), Proceedings of the 2nd International Conference on Information Management and Evaluation, (pp. 333-340), Reading, UK. 
Nielsen, J. (2011). Mobile content is twice as difficult. Retrieved November 12, 2014, from http://www.nngroup.com/articles/mobile-content-is-twice-as-difficult/

Nielsen, J., \& Budiu, R. (2013). Mobile Usability. Berkeley, CA: New Riders.

Norris, C., Hossain, A., \& Soloway, E. (2011). Using smartphones as essential tools for learning - A call to place schools on the right side of the 21st century. Educational Technology, 51(3), 18-25.

O'Malley, C., Vavoula, G., Glew, J. P., Taylor, J., Sharples, M., \& Lefrere, P. (2003).

MOBIlearn WP4 - Guidelines for learning/teaching/tutoring in a mobile environment. Retrieved November 4, 2014, from http://www.mobilearn.org/download/results/guidelines.pdf

Pachler, N., Bachmair, B., \& Cook, J. (2010). Mobile Learning: Structures, Agency, Practices. New York, NY: Springer.

Park, Y., \& Jung, Y.-J. (2013). Exploring the meaning of mobile learning for informal learning: Preliminary and exploratory study. International Journal of Knowledge Society Research, 4(2), 75-83.

Peters, K. (2007). m-Learning: Positioning educators for a mobile, connected future. International Review of Research in Open and Distance Learning, 8(2), 1-17.

Pocatilu, P. (2013). Developing an m-learning application for iOS. Informatica Economica, Academy of Economic Studies - Bucharest, Romania, 17(4), 77-86. 
Popescu, A.-I. (2011). Assessment of mobile learning contribution and practices in a lifelong learning society. International Journal of Arts \& Sciences, 4(8), 81-92.

Popescu, E., \& Ghita, D. (2013). Using social networking services to support learning. In J.-F. Wang \& R. Lau (Eds.), Advances in Web-based Learning ICWL 2013: 12th International Conference, Kenting, Taiwan, October 6-9, 2013: Proceedings (pp. 184193). Berlin, Germany: Springer.

Premkumar, K. (2011). Mobile learning in medicine. In A. Kitchenham (Ed.), Models for Interdisciplinary Mobile Learning: Delivering Information to Students (pp. 137-153). Hershey, PA: Information Science Reference.

Quinn, C. N. (2012). The Mobile Academy: mLearning for Higher Education. San Franscico, CA: John Wiles \& Sons Inc.

Rajasingham, L. (2011). Will mobile learning bring a paradigm shift in higher education? Education Research International, 1-10.

Rambe, P., \& Bere, A. (2013). Using social embeddedness to explore ubiquitous learning in mobile environments at a South African University of Technology. In: E. Ivala (Ed.), Proceedings of the 8th International Conference on e-Learning: ICEL 2013, Volume 1, (pp. 353-362), Cape Town, South Africa.

Rius, À., Masip, D., \& Clarisó, R. (2014). Student projects empowering mobile learning in higher education. RUSC, 11(1), 192-207. 
Rogers, K. D. (2011). Mobile Learning Devices. Bloomington, IN: Solution Tree Press.

Rosenberg, M. J. (2001). E-learning: Strategies for Delivering Knowledge in the Digital Age. New York, NY: McGraw-Hill.

Rung, A., Warnke, F., \& Mattheos, N. (2014). Investigating the use of smartphones for learning purposes by Australian dental students. JMIR mHealth uHealth, 2(2), 1-8.

Ryu, H., \& Parsons, D. (2012). Risky business or sharing the load? Social flow in collaborative mobile learning. Computers \& Education, 58(2), 707-720.

Sarrab, M., Al-Shihi, H., \& Hussain Rehman, O. M. (2013). Exploring major challenges and benefits of m-learning adoption. British Journal of Applied Science \& Technology, 3(4), 826-839.

Sarrab, M., Elgamel, L., \& Aldabbas, H. (2012). Mobile learning (M-Learning) and educational environments. International Journal of Distributed and Parallel Systems (IJDPS), 3(4), 31-38.

Seeholzer, J., \& Salem, J. A., Jr. (2011). Library on the go: A focus group study of the mobile Web and the academic library. College \& Research Libraries, 72(1), 9.

Sell, A., Walden, P., \& Carlsson, C. (2011). Segmentation matters: An exploratory study of mobile service users. International Journal of Systems and Service-Oriented Engineering, 2(3), 1-17. 
Serafimov, L. (2013). Mobile learning platforms. Paper presented at the 9th International Scientific Conference eLearning and software for Education Bucharest, Bucharest. Sharples, M. (2006). Big issues in Mobile Learning: Report of a Workshop by the Kaleidoscope Network of Excellence Mobile Learning Initiative. Nottingham, UK: University of Nottingham.

Sharples, M., Taylor, J., \& Vavoula, J. (2010). A theory of learning for the mobile age. In B. Bachmair (Ed.), Medienbildung in neuen Kulturräumen (pp. 87-99). Stuttgart, Germany: Kohlhammer Verlag.

Shih, J.-L., Hwang, G.-J., Chu, Y.-C., \& Chuang, C.-W. (2011). An investigation-based learning model for using digital libraries to support mobile learning activities. The Electronic Library, 29(4), 488-505.

Smith, S. D., Salaway, G., \& Caruso, J. (2009). The ECAR study of undergraduate students and information technology. Retrieved November 12, 2014, from https://net.educause.edu/ir/library/pdf/ers0906/rs/ERS0906w.pdf

Song, Y. (2011). Investigating undergraduate student mobile device use in context. In A. Kitchenham (Ed.), Models for Interdisciplinary Mobile Learning: Delivering Information to Students (pp. 120-136). Hershey, PA: Information Science Reference.

Stevens, D., \& Kitchenham, A. (2011). An analysis of mobile learning in education, business, and medicine. In A. Kitchenham (Ed.), Models for Interdisciplinary Mobile Learning: 
Delivering Information to Students (pp. 1-25). Hershey, PA: Information Science Reference.

Taraszow, T., Borghs, M., \& Laouris, Y. (2013). SMS or apps? A comparison using SWOT analysis. In W. K. S. Marshall (Ed.), On the Move: Mobile Learning for Development (pp. 43-68). Charlotte, NC: Information Age Publishing, Inc.

Ting, Y. R. (2012). Using mobile technologies to create interwoven learning interactions: An intuitive design and its evaluation. Computers \& Education, 60(1), 1-13.

Traxler, J. (2009). Learning in a mobile age. International Journal of Mobile and Blended Learning, 1(1), 1-12.

Traxler, J. (2010). Distance education and mobile learning: Catching up, taking stock. Distance Education, 31(2), 129-138.

Wagner, E. (2008). Realizing the promises of mobile learning. Journal of Computing in Higher Education, 20(2), 4-14.

Wang, Y. M., \& Wang, J. (2013). Research status and future trends of China’s mobile learning in recent 20 Years. Modern Distance Education Research, 10, 49-55.

Wesam, S., Gail, H., Elizabeth, F. G., \& Colin, H. (2013). Supporting interaction in learning activities using mobile devices in higher education. 12th World Conference on Mobile and Contextual Learning (mLearn 2013), 2013, 35. 
Wilson, S., \& McCarthy, G. (2010). The mobile university: From the library to the campus. Reference Services Review, 38(2), 214-232.

Yang, C.-C., Hwang, G.-J., Hung, C.-M., \& Tseng, S.-S. (2013). An evaluation of the learning effectiveness of concept map-based science book reading via mobile devices. Journal of Educational Technology \& Society, 16(3), 167-178. 


\section{Appendix}

Survey instrument used in the study (English version).

Part I: General Information

1. Please select your gender:

2. Please select your age category

3. Please select your Education level in Library and Information Management:

4. Which of the following mobile phone devices do you currently use?

$\diamond$ Simple mobile phone (cell phone) without Internet functions

$\diamond$ Simple mobile phone (cell phone) with Internet functions

$\diamond$ Smartphone with Internet subscription

$\diamond$ Smartphone without Internet subscription

$\diamond$ None of the above

5. What are your smartphone major features and functions? Please select all that applies.

$\diamond$ Touchscreen

$\diamond$ Full keypad

$\diamond$ Large display e.g. like size of an iPhone at least

$\diamond$ Small display, around $5.5 \mathrm{~cm}$ diagonally

$\diamond$ Ability to download and install apps

$\diamond$ Not applicable

6 . How often do you use the Internet from your smartphone even when a computer with Internet access is easily available?

7. In what typical occasions do you use the Internet with your smartphone? Please select all options that apply in your case.

$\diamond$ Use smartphone when computer is not available

$\diamond$ Use smartphone when I need quick answers

$\diamond$ Use smartphone because of lower costs than on other devices

$\diamond$ Use smartphone for reading some contents without being seen easily by others

$\diamond$ Use smartphone when I am away from my computer

$\diamond$ Smartphone is good to pass away waiting time

$\diamond$ Don't want to miss out on anything when on the go

$\diamond$ There is no other device with Internet access at home

$\diamond$ I don't have an Internet subscription on my smartphone

$\diamond$ Other (please specify) 
Part II. Using Smartphone for Everyday Needs and Purposes

8. Below is the list of types of applications for smartphones. Please indicate for each how often do you use them.

$\diamond$ Communicating with friends and family (e.g. email, SMS, chat)

$\diamond$ Social activities with social media (Facebook, Twitter, Goodreads, etc.).

$\diamond$ Finance and banking

$\diamond$ Shopping (Barcode Scanner, Amazon)

$\diamond$ Finding locations, like streets, restaurant, etc.

$\diamond$ Games, music, movies, TV series, etc.

$\diamond$ Hobbies, sports, fitness, travel

$\diamond$ Tools \& productivity software (calendar, notes, to-do lists)

$\diamond$ Casual reading: non-academic books, comics, magazines, newspaper, etc.

$\diamond$ Academic reading: Articles, e-books, blogs, websites.

$\diamond$ Accessing reference materials (e.g. Encyclopedia, dictionaries, etc.)

$\diamond$ Using search engines (e.g. Google, Yahoo, Baidu)

$\diamond$ Accessing libraries (e.g. HKPL, academic library)

$\diamond$ Others (please specify)

Part III. Using Smartphones for Study and Learning

9. Using smartphone for browsing, reading, viewing, listening for learning and study purposes:

$\diamond$ Browsing through Websites, blogs, wikis, micro-blogs, etc.

$\diamond$ Browsing or reading posts on social networking sites (e.g. Facebook, Whatsapp)

$\diamond$ Reading articles from professional journals \& magazines

$\diamond$ Reading e-books

$\diamond$ Listening to podcasts

$\diamond$ Viewing a video clip (from YouTube, TED talks or similar)

$\diamond$ Accessing and browsing learning management platform for information or resources (e.g. Moodle)

$\diamond$ Accessing other learning stuff (for learning foreign lanages, XML, etc.)

$\diamond$ Other (please specify)

10. Using smartphone for accessing information and doing searches for learning and study purposes:

$\diamond$ Accessing and searching library catalog

$\diamond$ Accessing reference sources (e.g., Encyclopedia, dictionary)

$\diamond$ Searching with search engines (e.g., Google, Yahoo!, etc.)

$\diamond$ Other (please specify) 
11. Using productivity tools on your smartphone for learning and study purposes:

$\diamond$ Making notes with note taking tools or memo tools (e.g. Evernote, T memo or similar)

$\diamond$ Creating documents (text, presentation, spreadsheets, etc.) with Google apps. or similar tools

$\diamond$ Planning or checking a personal schedule (e.g., Google Calendar, personal organizer)

$\diamond$ Other (please specify)

12. Using smartphone for communication and sharing (talking, texting, sending, posting) for learning and study purposes:

$\diamond$ Taking to classmates to discuss course materials, assignments, etc.

$\diamond$ Using email, SMS (text-messages), MMS or chat apps for study related issues with classmates/teachers

$\diamond$ Posting to class forums on the learning management platform (e.g., Moodle)

$\diamond$ Posting or commenting study related items to social networking sites (e.g., Facebook, Twitter, etc.)

$\diamond$ Posting study related items on social bookmarking sites (e.g., Delicision, Pinterest)

$\diamond$ Sending photos or videos from your smartphone to social networking sites

$\diamond$ Transport files (e.g., pdf, MS Word, MS PPT, etc.) of retrieved resources

$\diamond$ Scan QR codes (e.g., retrieved items from library catalog)

$\diamond$ Other (please specify)

13. Using smartphone for making and recording for learning and study purposes:

$\diamond$ Taking photos to record learning materials (e.g., book pages, slides)

$\diamond$ Recording your voice to create presentations

$\diamond$ Recording a formal interview (as a part of your research)

$\diamond$ Recording a seminar or other presentation by a speaker

$\diamond$ Creating videos for study purposes (e.g., presentations, assignments)

$\diamond$ Other (please specify)

14. Please list the apps that you use most frequently for learning purposes. (e.g., search engines, databases, libraries, social networking tools etc.):

$\diamond$ Browsing, reading, viewing, listening

$\diamond$ Accessing information and doing searches

$\diamond$ Productivity tools (e.g., document creation apps)

$\diamond$ Communication and sharing (e.g., talking, texting, sending and posting)

$\diamond$ Making and recording (e.g., picture, audio, video)

15. Is there any other way you use your smartphone for your learning and study? Please describe your experience. 
16. Do you consider the following factors as barriers to engaging in the online learning activities mentioned above by using a smartphone?

$\diamond$ Screen size is too small

$\diamond$ Web page is not formatted for smartphone

$\diamond$ Text typing is difficult

$\diamond$ Difficulty with authentication

$\diamond$ No WiFi or wireless where needed

$\diamond$ Difficulty with reading content format (e.g., PDF not sized correctly)

$\diamond$ Lack of a specialized mobile apps.

$\diamond$ Load time is slow

$\diamond$ Other (please specify)

17. Which of the following library services do you or would you like to use with your smartphone?

$\diamond$ Search library catalog - OPAC

$\diamond$ Search \& access electronic resources

$\diamond$ Access my library account

$\diamond \quad$ Book a seat, a computer or a study room

$\diamond \quad$ Check library hours, library map

$\diamond \quad$ Provide comments \& suggestions

$\diamond$ Contact librarian

$\diamond \quad$ Other (please specific) 


\section{FIGURES}

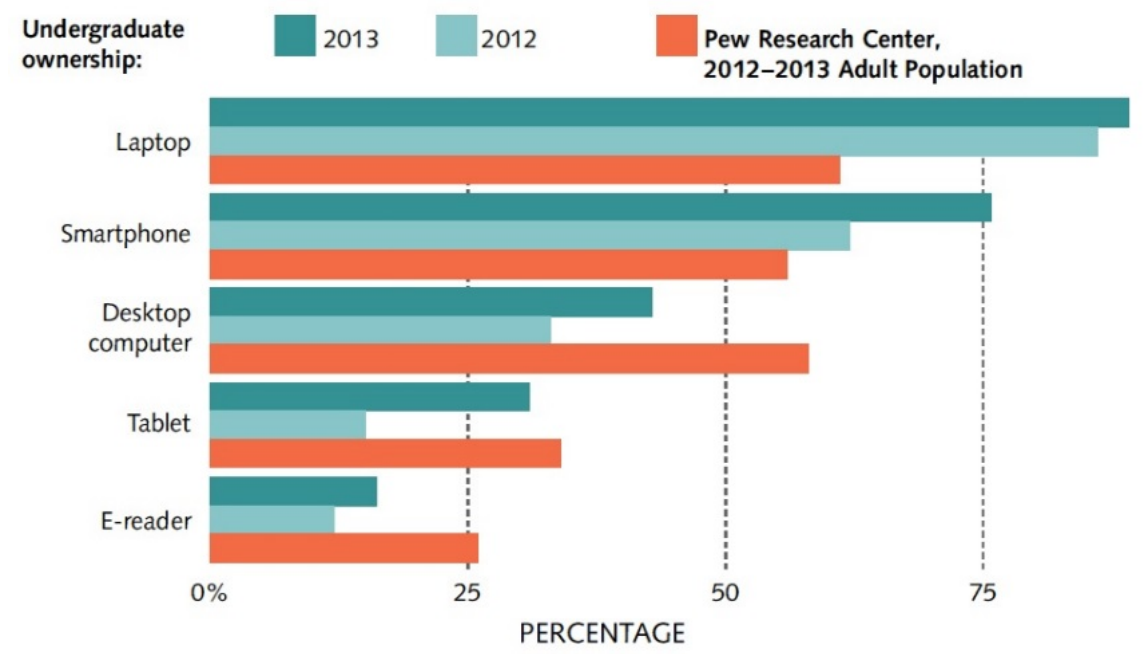

Fig. 1. 2012-2013 Device ownership comparisons (adopted from Dahlstrom et al. (2013)) 


\section{TABLES}

\section{Table 1}

Demographic background of our subjects.

\begin{tabular}{|c|c|c|c|c|}
\hline Demographic Type & $\begin{array}{c}\text { Hong Kong } \\
(\mathrm{N}=70)\end{array}$ & $\begin{array}{c}\text { Japan } \\
(\mathrm{N}=126)\end{array}$ & $\begin{array}{c}\text { Taiwan } \\
(\mathrm{N}=71)\end{array}$ & $\begin{array}{c}\text { Overall } \\
(\mathrm{N}=267)\end{array}$ \\
\hline \multicolumn{5}{|l|}{ Gender $(p>0.05)$} \\
\hline Male & 25 & 45 & 22 & 92 \\
\hline Female & 44 & 79 & 49 & 172 \\
\hline No Response & 1 & 2 & 0 & 3 \\
\hline \multicolumn{5}{|l|}{ Age $(p<0.01)$} \\
\hline$\leq 30$ & 33 & $117^{*}$ & 47 & 197 \\
\hline$>30$ & 37 & $7^{*}$ & 24 & 68 \\
\hline No Response & 0 & 2 & 0 & 2 \\
\hline \multicolumn{5}{|c|}{ Education Level $(p<0.01)$} \\
\hline Bachelor & $17^{*}$ & $82^{*}$ & $2^{*}$ & 101 \\
\hline Master or above & $53^{*}$ & $32^{*}$ & $68^{*}$ & 153 \\
\hline No Response & 0 & 12 & 1 & 13 \\
\hline \multicolumn{5}{|c|}{$\begin{array}{l}\text { Notes: } \\
{ }^{*} \text { value significantly different from the other countries based on Chi- } \\
\text { squarexxx test and Marascuilo procedure. }\end{array}$} \\
\hline
\end{tabular}

Table 2

Smartphone procession rate and Internet subscription.

\begin{tabular}{|c|c|c|c|c|}
\hline & $\begin{array}{c}\text { Hong Kong } \\
(\mathrm{N}=70)\end{array}$ & $\begin{array}{c}\text { Japan } \\
(\mathrm{N}=126)\end{array}$ & $\begin{array}{c}\text { Taiwan } \\
(\mathrm{N}=71)\end{array}$ & $\begin{array}{c}\text { Overall } \\
(\mathrm{N}=267)\end{array}$ \\
\hline \multicolumn{5}{|l|}{ Gender $(p<0.05)$} \\
\hline Smartphone & 64 & 108 & $70^{*}$ & 242 \\
\hline Cell phone and others & 6 & 14 & $1^{*}$ & 21 \\
\hline No Response & 0 & 4 & 0 & 4 \\
\hline \multicolumn{5}{|c|}{ Internet Subscription $(p<0.01)$} \\
\hline Yes & 62 & 104 & $60^{*}$ & 226 \\
\hline No & 2 & 4 & $10^{*}$ & 16 \\
\hline
\end{tabular}


Table 3

Smartphone usage in everyday life

\begin{tabular}{|c|c|c|c|c|}
\hline & Hong Kong & Japan & Taiwan & $\begin{array}{l}\text { Weighted } \\
\text { Average }\end{array}$ \\
\hline $\begin{array}{l}\text { Communication by voice, email or } \\
\text { Instant Messaging Tools }(p<0.01)\end{array}$ & $4.91^{*}$ & 4.50 & 4.67 & 4.69 \\
\hline $\begin{array}{l}\text { Social activities via social media } \\
\text { tools }(p>0.05)\end{array}$ & 4.30 & 4.32 & 4.49 & 4.37 \\
\hline Banking and finance $(p<0.01)$ & 2.01 & $1.50^{*}$ & 2.15 & 1.89 \\
\hline Shopping $(p>0.05)$ & 1.93 & 2.01 & 1.86 & 1.93 \\
\hline Find location/ using map ( $p>0.05)$ & 3.54 & 3.22 & 3.42 & 3.39 \\
\hline $\begin{array}{l}\text { Entertainment (e.g., games, music, } \\
\text { movies, TV series) }(p<0.01)\end{array}$ & $4.23^{*}$ & 3.48 & 3.87 & 3.86 \\
\hline $\begin{array}{l}\text { Information for travel, hobbies, } \\
\text { sport and fitness }(p<0.01)\end{array}$ & 3.12 & $2.61^{*}$ & 3.35 & 3.02 \\
\hline $\begin{array}{l}\text { Productivity tools (e.g., calendar, } \\
\text { notes, to-do list) }(p>0.05)\end{array}$ & 3.94 & 3.87 & 4.13 & 3.98 \\
\hline $\begin{array}{l}\text { Casual readings (e.g., non- } \\
\text { academic books, magazines, } \\
\text { comics, newspaper }(p<0.01)\end{array}$ & $3.98^{*}$ & 2.63 & 3.07 & 3.20 \\
\hline $\begin{array}{l}\text { Reference materials (e.g., } \\
\text { Encyclopedias, dictionaries) ( } p> \\
0.05 \text { ) }\end{array}$ & 3.35 & 3.03 & 3.07 & 3.15 \\
\hline Search engine $(p>0.05)$ & 4.44 & 4.43 & 4.26 & 4.38 \\
\hline Library services $(p<0.05)$ & $2.87^{*}$ & 2.48 & 2.38 & 2.58 \\
\hline \multicolumn{5}{|c|}{$\begin{array}{l}\text { Notes: } \\
\text { * value significantly different from the other countries based on ANOVAxxx test and Tukey- } \\
\text { Kramer multiple comparison. } \\
\text { Numerical value is assigned as: Never }=1 \text {; Less than Monthly }=2 \text {, Monthly }=3 \text {; Weekly }=4 \\
\text { Daily = } 5\end{array}$} \\
\hline
\end{tabular}




\section{Table 4}

Smartphone usage in everyday life for graduate students with smartphone with Internet connection.

\begin{tabular}{|c|c|c|c|c|}
\hline & Hong Kong & Japan & Taiwan & $\begin{array}{l}\text { Weighted } \\
\text { Average }\end{array}$ \\
\hline $\begin{array}{l}\text { Communication by voice, email or } \\
\text { Instant Messaging Tools }(p>0.05)\end{array}$ & 4.96 & 4.76 & 4.76 & 4.83 \\
\hline $\begin{array}{l}\text { Social activities via social media } \\
\text { tools }(p>0.05)\end{array}$ & 4.31 & 4.33 & 4.52 & 4.39 \\
\hline Banking and finance $(p>0.05)$ & 2.02 & 2.05 & 2.23 & 2.10 \\
\hline Shopping $(p>0.05)$ & 2.00 & 2.38 & 1.91 & 2.10 \\
\hline Find location/ using map ( $p>0.05)$ & 3.55 & 3.48 & 3.54 & 3.52 \\
\hline $\begin{array}{l}\text { Entertainment (e.g., games, music, } \\
\text { movies, TV series) }(p>0.05)\end{array}$ & 4.27 & 3.71 & 4.00 & 3.99 \\
\hline $\begin{array}{l}\text { Information for travel, hobbies, } \\
\text { sport and fitness }(p>0.05)\end{array}$ & 3.17 & 3.19 & 3.50 & 3.29 \\
\hline $\begin{array}{l}\text { Productivity tools (e.g., calendar, } \\
\text { notes, to-do list) }(p>0.05)\end{array}$ & 4.06 & 3.71 & 4.19 & 3.99 \\
\hline $\begin{array}{l}\text { Casual readings (e.g., non- } \\
\text { academic books, magazines, } \\
\text { comics, newspaper) }(p<0.01)\end{array}$ & $4.04^{*}$ & 2.79 & 3.04 & 3.29 \\
\hline $\begin{array}{l}\text { Reference materials (e.g., } \\
\text { Encyclopedias, dictionaries) ( } p> \\
0.05 \text { ) }\end{array}$ & 3.51 & 3.14 & 3.15 & 3.27 \\
\hline Search engine $(p>0.05)$ & 4.40 & 4.76 & 4.37 & 4.51 \\
\hline Library services $(p>0.05)$ & 2.76 & 2.43 & 2.30 & 2.49 \\
\hline \multicolumn{5}{|c|}{$\begin{array}{l}\text { Notes: } \\
\text { * value significantly different from the other countries based on ANOVA test and Tukey- } \\
\text { Kramer multiple comparison } x \text { Xx test. } \\
\text { Numerical value is assigned as: Never }=1 \text {; Less than Monthly }=2 \text {, Monthly = 3; Weekly = 4; } \\
\text { Daily = } 5\end{array}$} \\
\hline
\end{tabular}

Table 5

Circumstances that the respondents tend to use a smartphone to access Internet

\begin{tabular}{|c|c|c|c|c|}
\hline & Hong Kong & Japan & Taiwan & $\begin{array}{l}\text { Weighted } \\
\text { Average }\end{array}$ \\
\hline Computer is not available & 0.82 & 0.81 & 0.78 & 0.80 \\
\hline Quick answers is needed & 0.69 & 0.67 & 0.67 & 0.68 \\
\hline $\begin{array}{l}\text { I want to access to private } \\
\text { information }\end{array}$ & 0.20 & 0.24 & 0.13 & 0.19 \\
\hline $\begin{array}{l}\text { I want to pass away waiting / for } \\
\text { time-killing }\end{array}$ & 0.76 & 0.86 & 0.83 & 0.82 \\
\hline $\begin{array}{l}\text { I don't want to miss out anything } \\
\text { when on the go }\end{array}$ & 0.41 & 0.29 & 0.54 & 0.41 \\
\hline
\end{tabular}


Table 6

Accessing to the Internet by smartphone even though computer is easily available

\begin{tabular}{|c|c|c|c|c|}
\hline & Hong Kong & Japan & Taiwan & $\begin{array}{l}\text { Weighted } \\
\text { Average }\end{array}$ \\
\hline $\begin{array}{l}\text { Access Internet by smartphone even } \\
\text { computer is is easily available } \\
(p<0.01)\end{array}$ & $4.12^{*}$ & 3.20 & 3.30 & 3.54 \\
\hline \multicolumn{5}{|c|}{$\begin{array}{l}\text { Notes: } \\
\text { * value significantly different from the other countries based on ANOVA test and Tukey- } \\
\text { Kramer multiple comparison } x \text { Xx test. } \\
\text { Numerical value is assigned as: Never }=1 \text {; Less than Monthly }=2 \text {, Monthly = 3; Weekly = 4; } \\
\text { Daily = } 5\end{array}$} \\
\hline
\end{tabular}

Table 7

Browsing, reading, viewing and listening habits of our subjects

\begin{tabular}{|c|c|c|c|c|}
\hline & Hong Kong & Japan & Taiwan & $\begin{array}{l}\text { Weighted } \\
\text { Average }\end{array}$ \\
\hline \multicolumn{5}{|l|}{ Overall } \\
\hline $\begin{array}{l}\text { Browsing websites, blogs, wikis ( } p> \\
0.05 \text { ) }\end{array}$ & 3.55 & 3.57 & 3.45 & 3.52 \\
\hline Reading posts in social media $(p<0.01)$ & 4.16 & $3.28^{*}$ & 4.21 & 3.88 \\
\hline Reading journals $(p<0.01)$ & 2.47 & $1.56^{*}$ & 2.54 & 2.19 \\
\hline Reading e-books $(p<0.01)$ & 2.29 & $1.72^{*}$ & 2.39 & 2.13 \\
\hline Listening to a Podcast $(p<0.01)$ & $1.92^{*}$ & 1.40 & 1.66 & 1.66 \\
\hline Viewing video clips $(p<0.01)$ & 3.23 & $2.48^{*}$ & 3.10 & 2.94 \\
\hline Accessing learning platform $(p<0.01)$ & $2.61^{*}$ & $1.43^{*}$ & $1.98^{*}$ & 2.01 \\
\hline \multicolumn{5}{|l|}{ Restricted } \\
\hline $\begin{array}{l}\text { Browsing websites, blogs, wikis ( } p> \\
0.05 \text { ) }\end{array}$ & 3.69 & 4.10 & 3.55 & 3.78 \\
\hline Reading posts in social media $(p>0.05)$ & 4.20 & 3.60 & 4.24 & 4.02 \\
\hline Reading journals $(p>0.05)$ & 2.47 & 1.90 & 2.48 & 2.28 \\
\hline Reading e-books $(p>0.05)$ & 2.22 & 2.10 & 2.49 & 2.27 \\
\hline Listening to a Podcast $(p>0.05)$ & 1.82 & 1.80 & 1.63 & 1.75 \\
\hline Viewing video clips $(p>0.05)$ & 3.36 & 2.75 & 3.12 & 3.08 \\
\hline Accessing learning platform $(p<0.01)$ & $2.76^{*}$ & 1.70 & 1.98 & 2.15 \\
\hline \multicolumn{5}{|c|}{$\begin{array}{l}\text { Notes: } \\
\text { * } \text { value significantly different from the other countries based on ANOVA test and Tukey- } \\
\text { Kramer multiple comparison } x x x \text { test. } \\
\text { Numerical value is assigned as: Never = } 1 \text {; Less than Monthly = 2, Monthly = 3; Weekly = 4; } \\
\text { Daily = } 5\end{array}$} \\
\hline
\end{tabular}


Table 8

Searching and accessing information for learning purpose

\begin{tabular}{|c|c|c|c|c|}
\hline & Hong Kong & Japan & Taiwan & $\begin{array}{l}\text { Weighted } \\
\text { Average }\end{array}$ \\
\hline \multicolumn{5}{|l|}{ Overall } \\
\hline Library catalog $(p<0.01)$ & $2.58^{*}$ & 2.02 & 2.37 & 2.32 \\
\hline Library e-Database $(p<0.01)$ & $2.13^{*}$ & 1.54 & 1.87 & 1.84 \\
\hline $\begin{array}{l}\text { Reference materials (e.g. Encyclopedia, } \\
\text { dictionary) }(p>0.05)\end{array}$ & 3.03 & 2.55 & 2.61 & 2.73 \\
\hline Search engine $(p>0.05)$ & 4.02 & 3.58 & 3.79 & 3.79 \\
\hline \multicolumn{5}{|l|}{ Restricted } \\
\hline Library catalog $(p>0.05)$ & 2.49 & 2.15 & 2.35 & 2.33 \\
\hline Library e-Database $(p>0.05)$ & 2.00 & 1.65 & 1.84 & 1.83 \\
\hline $\begin{array}{l}\text { Reference materials (e.g. Encyclopedia, } \\
\text { dictionary) }(p>0.05)\end{array}$ & 3.16 & 2.60 & 2.61 & 2.79 \\
\hline Search engine $(p>0.05)$ & 4.07 & 3.75 & 3.8 & 3.87 \\
\hline \multicolumn{5}{|c|}{$\begin{array}{l}\text { Notes: } \\
{ }_{*}^{*} \text { value significantly different from the other countries based on } \underline{\text { ANOVA test and Tukey- }} \\
\text { Kramer multiple comparisonxxx test. } \\
\text { Numerical value is assigned as: Never = } 1 \text {; Less than Monthly }=2 \text {, Monthly = } 3 \text {; Weekly }=4 \text {; } \\
\text { Daily = } 5\end{array}$} \\
\hline
\end{tabular}

Table 9

Using of productivity tools for learning purpose

\begin{tabular}{|c|c|c|c|c|}
\hline & Hong Kong & Japan & Taiwan & $\begin{array}{l}\text { Weighted } \\
\text { Average }\end{array}$ \\
\hline \multicolumn{5}{|l|}{ Overall } \\
\hline Making notes $(p>0.05)$ & 2.78 & 2.36 & 2.69 & 2.61 \\
\hline Creating documents $(p<0.01)$ & 2.05 & $1.58^{*}$ & 2.25 & 1.96 \\
\hline Scheduling and planning $(p<0.01)$ & 3.21 & $2.59^{*}$ & 3.35 & 3.05 \\
\hline \multicolumn{5}{|l|}{ Restricted } \\
\hline Making notes $(p>0.05)$ & 2.96 & 2.35 & 2.90 & 2.73 \\
\hline Creating documents $(p>0.05)$ & 2.09 & 1.75 & 2.31 & 2.05 \\
\hline Scheduling and planning $(p>0.05)$ & 3.47 & 2.75 & 3.48 & 3.23 \\
\hline \multicolumn{5}{|c|}{$\begin{array}{l}\text { Notes: } \\
\text { * value significantly different from the other countries based on ANOVA test and Tukey- } \\
\text { Kramer multiple comparison } x x x \text { test. } \\
\text { Numerical value is assigned as: Never = 1; Less than Monthly = 2, Monthly = 3; Weekly = 4; } \\
\text { Daily = } 5\end{array}$} \\
\hline
\end{tabular}


Table 10

Communicating, sharing, and collaborating for learning purpose

\begin{tabular}{|c|c|c|c|c|}
\hline & Hong Kong & Japan & Taiwan & $\begin{array}{l}\text { Weighted } \\
\text { Average }\end{array}$ \\
\hline \multicolumn{5}{|l|}{ Overall } \\
\hline Voice discussion $(p<0.01)$ & 3.45 & $2.69^{*}$ & 3.40 & 3.18 \\
\hline $\begin{array}{l}\text { Texting by email or instant messaging } \\
\text { tools }(p<0.01)\end{array}$ & 3.58 & $2.95^{*}$ & 3.6 & 3.38 \\
\hline $\begin{array}{l}\text { Posting or commenting in class forums } \\
(p<0.01)\end{array}$ & 2.32 & $1.19^{*}$ & 2.02 & 1.84 \\
\hline $\begin{array}{l}\text { Posting or commenting in social media } \\
(p<0.01)\end{array}$ & 2.59 & $2.06^{*}$ & 2.97 & 2.54 \\
\hline $\begin{array}{l}\text { Posting on social bookmarking site }(p< \\
0.01)\end{array}$ & 1.75 & $1.23^{*}$ & 1.81 & 1.60 \\
\hline $\begin{array}{l}\text { Sharing video or photos in social media } \\
(p<0.01)\end{array}$ & 2.60 & $2.05^{*}$ & 2.81 & 2.49 \\
\hline $\begin{array}{l}\text { Sharing or retrieving files and documents } \\
(p<0.01)\end{array}$ & 2.58 & $2.01^{*}$ & 2.98 & 2.52 \\
\hline Scanning QR code $(p<0.01)$ & 1.73 & 1.69 & $2.13^{*}$ & 1.85 \\
\hline \multicolumn{5}{|l|}{ Restricted } \\
\hline Voice discussion $(p<0.05)$ & 3.38 & $2.50^{*}$ & 3.44 & 3.11 \\
\hline $\begin{array}{l}\text { Texting by email or instant messaging } \\
\text { tools }(p>0.05)\end{array}$ & 3.56 & 3.40 & 3.75 & 3.57 \\
\hline $\begin{array}{l}\text { Posting or commenting in class forums } \\
(p<0.01)\end{array}$ & $2.45^{*}$ & 1.30 & 1.94 & 1.90 \\
\hline $\begin{array}{l}\text { Posting or commenting in social media } \\
(p>0.05)\end{array}$ & 2.69 & 2.05 & 2.96 & 2.57 \\
\hline $\begin{array}{l}\text { Posting on social bookmarking site }(p> \\
0.05)\end{array}$ & 1.78 & 1.30 & 1.85 & 1.64 \\
\hline $\begin{array}{l}\text { Sharing video or photos in social media } \\
(p>0.05)\end{array}$ & 2.64 & 2.20 & 2.83 & 2.55 \\
\hline $\begin{array}{l}\text { Sharing or retrieving files and documents } \\
(p>0.05)\end{array}$ & 2.53 & 2.50 & 3.04 & 2.69 \\
\hline Scanning QR code $(p>0.05)$ & 1.84 & 1.60 & 2.13 & 1.86 \\
\hline \multicolumn{5}{|c|}{$\begin{array}{l}\text { Notes: } \\
\text { *alue significantly different from the other countries based on ANOVA test and Tukey- } \\
\text { Kramer multiple comparison } x x x \text { test. } \\
\text { Numerical value is assigned as: Never = } 1 \text {; Less than Monthly = 2, Monthly = 3; Weekly = 4; } \\
\text { Daily = } 5\end{array}$} \\
\hline
\end{tabular}




\section{Table 11}

Record making for learning purpose

\begin{tabular}{|c|c|c|c|c|}
\hline & Hong Kong & Japan & Taiwan & $\begin{array}{l}\text { Weighted } \\
\text { Average }\end{array}$ \\
\hline \multicolumn{5}{|l|}{ Overall } \\
\hline $\begin{array}{l}\text { Photo taking of learning materials }(p< \\
0.01)\end{array}$ & 3.02 & $2.35^{*}$ & 3.11 & 2.83 \\
\hline $\begin{array}{l}\text { Recording voice for presentations ( } p< \\
0.05 \text { ) }\end{array}$ & 1.56 & $1.36^{*}$ & 1.70 & 1.54 \\
\hline Recording a formal interview $(p<0.01)$ & 1.59 & $1.13^{*}$ & 1.75 & 1.49 \\
\hline Recording a seminar or talk $(p<0.01)$ & 1.67 & $1.21^{*}$ & 1.90 & 1.59 \\
\hline Creating video $(p<0.01)$ & $1.45^{*}$ & $1.11^{*}$ & $2.05^{*}$ & 1.54 \\
\hline \multicolumn{5}{|l|}{ Restricted } \\
\hline $\begin{array}{l}\text { Photo taking of learning materials }(p> \\
0.05)\end{array}$ & 3.00 & 2.55 & 3.13 & 2.89 \\
\hline $\begin{array}{l}\text { Recording voice for presentations ( } p> \\
0.05 \text { ) }\end{array}$ & 1.53 & 1.60 & 1.60 & 1.58 \\
\hline Recording a formal interview $(p>0.05)$ & 1.60 & 1.20 & 1.75 & 1.52 \\
\hline Recording a seminar or talk $(p<0.01)$ & 1.62 & $1.10^{*}$ & 1.92 & 1.55 \\
\hline Creating video $(p<0.01)$ & 1.44 & 1.05 & $2.02^{*}$ & 1.51 \\
\hline \multicolumn{5}{|c|}{$\begin{array}{l}\text { Notes: } \\
\text { * value significantly different from the other countries based on ANOVA test and Tukey- } \\
\text { Kramer multiple comparison }\end{array}$} \\
\hline
\end{tabular}


Table 12

Library services accessed via smartphone

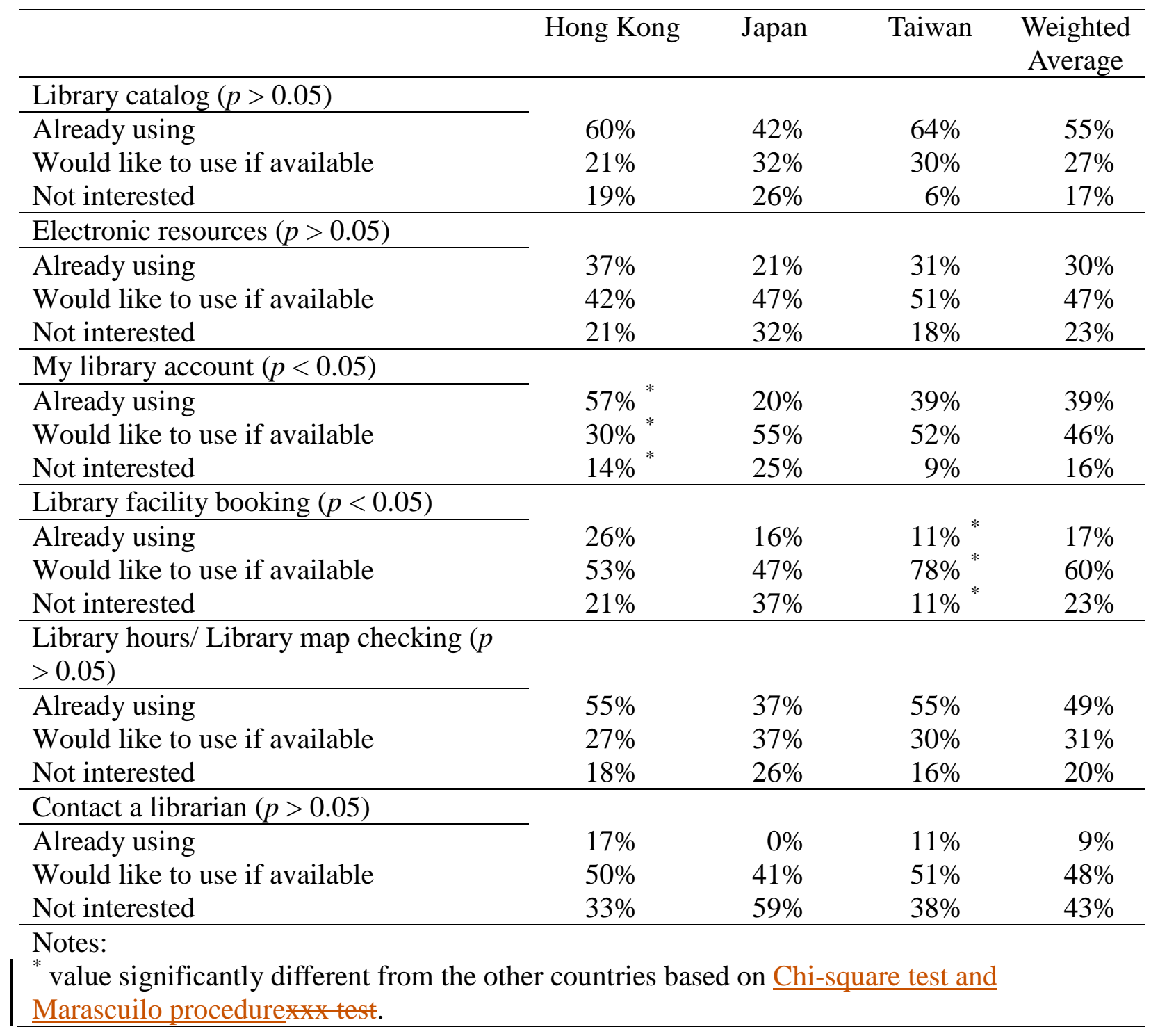


Table 13

Barriers when engaging in m-learning using restricted data set

\begin{tabular}{|c|c|c|c|c|}
\hline & Hong Kong & Japan & Taiwan & $\begin{array}{l}\text { Weighted } \\
\text { Average }\end{array}$ \\
\hline Small screen size $(p>0.05)$ & 3.43 & 3.30 & 3.08 & 3.27 \\
\hline $\begin{array}{l}\text { Lack of mobile version website ( } p> \\
0.05 \text { ) }\end{array}$ & 3.44 & 3.05 & 3.35 & 3.28 \\
\hline Difficulty in typing $(p>0.05)$ & 3.11 & 2.80 & 3.00 & 2.97 \\
\hline Difficulty with authentication $(p>0.05)$ & 2.70 & 2.58 & 2.91 & 2.73 \\
\hline WiFi and network problem $(p<0.05)$ & 2.71 & 2.55 & $3.30^{*}$ & 2.85 \\
\hline $\begin{array}{l}\text { Formatting problems when reading } \\
\text { content on different devices }(p>0.05)\end{array}$ & 3.16 & 3.16 & 3.13 & 3.15 \\
\hline Lack of mobile apps $(p>0.05)$ & 2.78 & 2.85 & 2.74 & 2.79 \\
\hline Loading time $(p>0.05)$ & 3.09 & 3.00 & 3.04 & 3.04 \\
\hline \multicolumn{5}{|c|}{$\begin{array}{l}\text { Notes: } \\
\text { * value significantly different from the other countries based on ANOVA test and Tukey- } \\
\text { Kramer multiple comparison } x \text { xx test. } \\
\text { Numerical value is assigned as: Not a barrier at all = 1; Low barrier = 2; Medium barrier =3; } \\
\text { High barrier }=4 \text {. }\end{array}$} \\
\hline
\end{tabular}

Table 14

Hofstede cultural dimensions of Hong Kong, Japan, and Taiwan.

\begin{tabular}{lccccc}
\hline Country & $\begin{array}{l}\text { Power } \\
\text { Distance }\end{array}$ & Individualism & Masculinity & $\begin{array}{c}\text { Uncertainty } \\
\text { Avoidance }\end{array}$ & $\begin{array}{c}\text { Long-term } \\
\text { Orientation }\end{array}$ \\
\hline Hong Kong & 68 & 25 & 57 & 29 & 61 \\
Japan & 54 & 46 & 95 & 92 & 88 \\
Taiwan & 58 & 17 & 45 & 69 & 93 \\
\hline Notes: Data & obtained from http:/geert-hofstede.com/cultural-tools.html
\end{tabular}

